\title{
KONSEP DAN IMPLEMENTASI AKAD QARDHUL HASAN PADA PERBANKAN SYARIAH DAN MANFAATNYA
}

\author{
${ }^{1}$ Febri Annisa Sukma, ${ }^{2}$ Refki Kurniadi Akbar, ${ }^{3}$ Nuri Nur Azizah, ${ }^{4}$ Giri Putri Juliani \\ Jurusan Hukum Ekonomi Syariah Fakultas Syariah Universitas Islam Bandung \\ Jl. Tamansari No. 1 Bandung \\ ${ }^{1}$ febryannisaaa@gmail.com, ${ }^{2}$ refki.kurniadi.akbar@gmail.com, ${ }^{3}$ nurinazizah74@ gmail.com, \\ giripjuliani@gmail.com.
}

\begin{abstract}
Abstrak
Perbankan syariah dalam melakukan kegiatan usahanya tidak hanya mengejar keuntungan, tetapi juga memiliki fungsi sosial dimasyarakat yang direalisasikan dalam bentuk akad qardh/qardhul hasan atau pinjaman kebajikan di mana sumber dananya berasal dari zakat, infaq, sedekah, hibah dan dana sosial lainnya. Tujuan Penelitian ini adalah untuk mengetahui Konsep Akad Qardhul Hasan dalam Fikih Muamalah dan mengetahui Implementasi serta Praktik Akad tersebut di Perbankan Syariah. Penelitian ini menggunakan metode analisis deskriptif dengan mengidentifikasi dari beberapa sumber antara lain buku, jurnal, website, Al-Qur'an dan Hadits sehingga dapat digambarkan bahwa Implementasi dan Praktik Akad Qardhul Hasan sudah sesuai dengan Konsep Akad Qardhul Hasan dalam Fikih Muamalah. Dari hasil penelitia ini dapat disimpulkan bahwa perbankan syariah dalam mengimplementaskan akad Qardh Hasan tersebut merupakan salah satu bentuk tolong menolong kepada masyarakat dan memberikan banyak manfaat.
\end{abstract}

Kata Kunci : Perbankan Syariah, Qardhul Hasan, Manfaat.

\begin{abstract}
Islamic banking in conducting its business activities is not only pursuing profits, but also has social functions in the community that are realized in the form of qardh / qardhul hasan contract or loan virtues where the source of funds comes from zakat, infaq, Shadaqah, Hibah and other social funds. The purpose of this study was to find out the concept of the Qardhul Hasan contract in Fiqh Muamalah and to know the Implementation and Practice of the Contract in Islamic Banking. This research uses descriptive analysis method by identifying from several sources including books, journals, websites, Al-Qur'an and Hadith so that it can be described that the Implementation and Practice of the Qardhul Hasan Agreement is in accordance with the Concept of Qardhul Hasan Agreement in Fiqh Muamalah. From the results of this study it can be concluded that Islamic banking in implementing the Qardh Hasan contract is a form of to help the community and provide many benefits.
\end{abstract}

Keywords : Islamic Banking, Qardhul Hasan, Benefit.

I. PENDAHULUAN

\section{A. Latar Belakang}

Secara umum, bank sebagai intermediary finance adalah lembaga yang melaksanakan tiga fungsi utama, yaitu menghimpun dana (Funding) baik berupa tabungan, deposito, giro kemudian menyalurkan dana (Landing) yang direalisasikan berupa kredit (konvensional)

Received: 2019-01-04 | Reviced: 2019-07-29 | Accepted: 2019-07-30

Diindeks : Sinta, DOAJ, Garuda, CrossRef, Google Scholar | DOI: https://doi.org/10.29313/amwaluna.v3i2.4296 
atau pembiayaan (syariah) dan memberikan pelayanan jasa lainnya.

Perbankan syariah merupakan institusi/lembaga keuanagn yang tumbuh dan berkembang di Indonesia sejak 16 tahun yang lalu diawali dengan berdirinya Bank Muamalat Indonesia. Perkembangan bank syariah diikuti dengan berkembangnya lembaga keuangan syariah di luar struktur perbankan (Imaniyati P. D., 2009).

Di Indonesia saat ini sektor perbankan semakin berkembang, terutama perbankan yang menggunakan prinsip hukum islam atau disebut Bank Syariah yang mempunyai asas seperti disebutkan dalam Pasal 2 Undang-undang No. 21 tahun 2008 tentang Perbankan Syariah yang menegaskan bahwa "Perbankan Syariah dalam melakukan kegiatan usahanya berdasarkan prinsip syariah, demokrasi, dan prinsip kehati-hatian”. Dari ketentuan Undang-undang tersebut dapat diketahui secara jelas bahwa perbankan syariah dalam melakukan kegiatan usaha diwajibkan berasaskan dan mengimplementasikan prinsip syariah. (Dr. Neneng Nurhasanah \& Panji Adam, 2017)

Itulah yang membedakan Bank Syariah dengan Bank Konvensional, selain perbankan yang menjalankan usahanya berdasarkan prinsip syariah atau hukum islam tetapi juga memiliki dwifungsi di masyarakat. Fungsi bank syariah selaku pelaku bisnis tidak hanya mengejar keuntungan tetapi juga mempunyai fungsi sosial (tabarru') dalam bentuk lembaga baitul mal, yaitu menerima dana yang berasal dari zakat, infak, sedekah, hibah, atau dana sosial lainnya yang menyalurkannya kepada organisasi pengelolaan zakat kemudian menghimpun dana sosial yang berasal dari wakaf uang. (Dr. Neneng Nurhasanah \& Panji Adam, 2017)

Fungsi sosial tersebut pada Bank Syariah direalisasikan dalam bentuk akad Qardh dan turunannya Qardhul Hasan. Satu-satunya akad berbentuk pinjaman uang atau modal yang diterapkan dalam perbankan syariah. Karena bunga dilarang dalam Islam, maka pinjaman Qardh maupun Qardhul Hasan merupakan pinjaman tanpa bunga. Akad ini merupakan akad pinjaman kebajikan yang diberikan kepada nasabah sebagai pinjaman uang maupun pinjaman untuk modal usaha yang tidak bersifat komersial, tetapi bersifat sosial (Ascarya, 2007) dimana sumber dana yang dipinjamkan bersumber dari dana sosial seperti zakat, infak, sedekah, hibah, wakaf uang dan dana sosial lainnya.

Dalam hal ini peminjam memiliki tanggungjawab untuk mengembalikan 
pinjaman Qardh tersebut sesuai dengan jumlah yang dipinjamnya tanpa bergantung pada untung atau rugi usaha yang dijalankannya. Sedangkan Qardhul Hasan yaitu meminjamkan sesuatu kepada nasabah, dimana pihak nasabah sebenarnya tidak ada kewajiban untuk mengembalikannya.

Jadi seperti apa sebenarnya Konsep Qardh dalam Fikih Muamalah dan bagaimana implementasi atau praktiknya di lembaga keuangan khususnya di Perbankan Syariah serta apa manfaatnya. Dalam artikel ini kami akan membahas lebih dalam mengenai akad Qardh yang menjadi salah satu pembeda antara Bank Syariah dan Bank Konvensional, mulai dari Konsep Qardh dalam Fikih Muamalah sampai kepada implementasi dan praktiknya di Bank Syariah beserta manfaatnya bagi nasabah maupun Bank Syariah itu sendiri.

\section{B. Rumusan Masalah}

Untuk sampai kepada tujuan sebagaimana pengantar di atas, kami akan merumuskan beberapa hal yang akan kami bahas dalam artikel ilmiah ini, diantaranya:

1. Definisi Qardh dan Qardhul Hasan menurut Fikih Muamalah, UndangUndang Perbankan Syariah dan DSNMUI.

2. Rukun dan Syarat Akad Qardh.
3. Dasar Hukum Qardh dalam Al-Qur'an, Hadits, maupun Ijma'.

4. Akad Qardh sebagai Akad Tabarru'

5. Ketentuan akad Qardh berdasar pada Fatwa DSN-MUI

6. Implementasi dan praktik akad Qardh di Perbankan Syariah.

7. Anjuran menyegerakan pengembalian Pinjaman Qardh

8. Manfaat akad Qardh dan Qardhul Hasan

\section{Tujuan Pembahasan}

Berdasarkan rumusan masalah yang diuraikan di atas, maka tujuan penulisan artikel ilmiah ini untuk mengungkapkan tentang:

1. Pemahaman tentang Definisi Qardh dan Qardhul Hasan dari pandangan Fikih Muamalah, Kompilasi Hukum Ekonomi Syariah dan Fatwa DSNMUI.

2. Mengetahui Rukun dan Syarat akad Qardh.

3. Mengetahui dasar hukum Qardh dalam Al-Qur'an, Hadits maupun Ijma'.

4. Mengetahui akad Qardh sebagai akad Tabarru'

5. Mengetahui ketentuan akad Qardh berdasar pada Fatwa DSN-MUI

6. Mengetahui bagaimana implementasi dan praktik akad Qardh di Perbankan Syariah. 
7. Mengetahui anjuran untuk menyegerakan pembayaran pinjaman Qardh

8. Mengetahui manfaat dari akad Qardh

\section{Metode Penelitian}

Metode penelitian yang digunakan dalam pembuatan artikel ilmiah ini adalah dengan metode deskriptif analisis yaitu mengumpulkan, mempelajari dan menganalisa masalah yang ada kaitannya dengan penelitian di atas. Sedangkan teknik pengumpulan data ditempuh melalui library research dengan beberapa upaya yang ditempuh yaitu mengumpulkan buku-buku sumber dan beberapa jurnal artikel ilmiah yang berkaitan dengan akad dan produk Bank Syariah, setelah itu kami ambil salah satu akad dan produk Bank Syariah untuk diteliti yaitu akad Qardh. Dari beberapa sumber tersebut kami persempit lagi untuk diteliti, dimana akan kami teliti mulai dari konsep akad Qardh dalam Fikih Muamalah, implementasi dan praktiknya pada Bank Syariah beserta manfaatnya.

\section{PEMBAHASAN}

\section{A. Landasan Teori Qardh}

1. Definisi Qardh

Qardh secara bahasa berasal dari kata al-Qath' harta yang dipinjamkan merupakan bagian dari harta milik pihak yang memberi pinjaman. Maksudnya, jadi harta yang di pinjamkan kepada seseorang itu bukan milik orang lain tetapi miliknya sendiri. (Sjahdeini \& Remy, 1999)

Sayyid Sabiq memberikan definisi qardh sebagai berikut:

$$
\begin{aligned}
& \text { الْقَرْضُ هُوَ الََْالُ الَّذِيْ يُعْطِيْهِه الْمَفْرِضُ }
\end{aligned}
$$

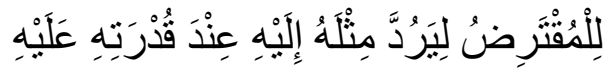

"Al-Qardh adalah harta yang diberikan oleh pemberi hutang (muqridh) kepada penerima utang (muqtarid) untuk kemudian dikembalikan kepadanya (muqridh) seperti yang diterimanya, ketika ia telah mampu membayarnya." (Sjahdeini \& Remy, 1999)

Menurut ulama Hanafiah, Qardh adalah:

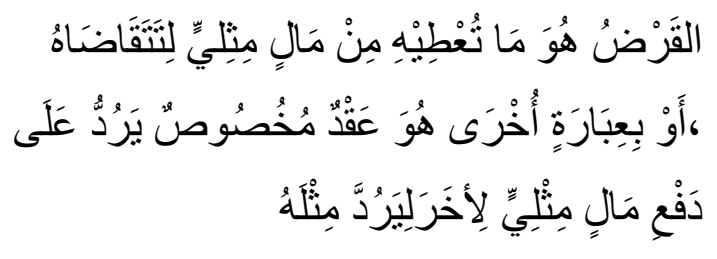

"Qardh adalah harta yang diberikan seseorang dari harta mitsli (yang memiliki perumpamaan) untuk kemudian dibayar atau dikembalikan. Atau dengan ungkapan yang lain, qardh adalah suatu perjanjian yang khusus untuk menyerahkan harta (mal mitsli) kepada orang lain untuk kemudian dikembalikan persis seperti yang diterimanya."

Dari definisi menurut ahli fiqih tersebut Qardh berarti suatu pinjaman harta yang diberikan kepada pihak yang meminjam yang dikemudian hari 
Febri Annisa Sukma, dkk. Konsep dan Implementasi Akad Qardhul Hasan Pada Perbankan Syariah dan Manfaatnya

peminjam itu wajib atau harus mengembalikan harta pinjaman tersebut sesuai dengan jumlah harta yang dipinjamnya ketika peminjam sudah mampu untuk membayarnya.

Akad Qardh di Indonesia diatur pada Peraturan Bank Indonesia Nomor 7/46/PBI/2015 tentang Qardh diartikan sebagai pinjam meminjam dana tanpa imbalan dengan kewajiban pihak peminjam mengembalikan pokok pinjaman secara sekaligus atau cicilan dalam waktu tertentu. (Usanti, 2017)

Menurut Kompilasi Hukum Ekonomi Syari'ah (KHES) Qardh adalah penyediaan dana atau tagihan antarlembaga keuangan syari'ah dengan pihak peminjam yang mewajibkan pihak peminjam untuk melakukan pembayaran secara tunai atau cicilan dalam jangka waktu tertentu. (Masruri, Zainur, \& Khairul, 2018)

Menurut Fatwa DSN No. 19/DSNMUI/IV/2001, Al-Qardh adalah pinjaman yang diberikan kepada nasabah (muqtaridh) yang memerlukan. Nasabah Al-Qardh wajib mengembalikan jumlah pokok yang diterima pada waktu yang telah disepakati bersama. (Masruri, Zainur, \& Khairul, 2018)

Antara Qardh dengan Qardhul Hasan ada beberapa pakar yang menyamakan keduanya. Misal dinyatakan bahwa Qardh atau Qardh Al-Hasan : is aloan extended without interest or any other compensation from borowwer. The lender expects a reward only from God (Research \& Institute, 2007). Menurut Sjahdeini (2014), Qardhul Hasan adalah perjanjian Qardh yang khusus untuk tujuan sosial. Penerima Qardhul Hasan hanya diharuskan untuk melunasi jumlah pokok pinjaman tanpa harus memberikan tambahan apapun. (Satrio, 2009)

Dari beberapa definisi di atas dapat disimpulkan bahwa akad Qardh pada hakikatnya adalah bentuk pertolongan dan kasih sayang bagi yang meminjam, bukan suatu sarana untuk mencari keuntungan bagi yang memijamkan, di dalamnya tidak ada imbalan dan kelebihan pengembalian. Namun dalam Qardh ini mengandung nilai kemanusiaan dan sosial dimana dalam akad ini peminjam tidak boleh mensyaratkan keuntungan dalam pinjaman dan ia boleh menerima lebih jika peminjam memberikannya dalam jumlah yang lebih selama tidak dipersyaratkan di awal dan tidak diperjanjikan.

2. Rukun dan Syarat Akad Qardh

1) Rukun Qardh

Rukun Qardh menurut ulama Hanafiyah adalah ijab dan kabul. Sementara menurut Jumhur ulama rukun Qardh ada tiga, yaitu: 1) dua orang yang 
berakad yang terdiri dari: muqridh (yang memberikan utang) dan muqtaridh (orang yang berutang), 2) Qardh (barang atau objek yang dipinjamkan), 3) shigat ijab dan kabul. (Usanti, 2017) Dengan demikian, syarat sahnya diperbolehkan untuk melakukan Qardh memang harus ada keseluruhan rukun tersebut. Jika salah satunya tidak ada, maka peminjaman tersebut dinyatakan tidak sah secara hukum islam.

Ijab dan kabul dalam Qardh sama seperti ijab kabul dalam jual-beli. Ijab dan kabul dalam Qardh, merupakan ucapan yang disampaikan langsung oleh peminjam kepada penerima pinjaman bahwa peminjam mengijinkan secara langsung uang tersebut dipinjam. Keduanya saling ridha terhadap akad tersebut.

2) Syarat Qardh

Ketentuan dan syarat harta qardh dari segi kepemilikan berlaku ketentuan dan syarat al-mabi' (benda yang diperjualbelikan), yaitu harta yang diqardh-kan harus milik muqridh karena sifat al-tamlik-nya sama, yaitu harta Qardh berpindah kepemilikannya dari milik muqridh menjadi milik muqtaridh sehingga muqridh harus memiliki hak untuk memindahkan kepemilikan barang yang di qardh-kan.
Harta yang boleh dijadikan objek akad Qardh harus harta yang miliknya yang disepakati ukurannya, baik secara kuantitas maupun kualitasnya.

Personalia akad (muqridh) harus termasuk pihak yang memiliki kemampuan untuk melakukan tabarru' karena akad qardh termasuk akad yang menyebabkan terjadinya perpindahan kepemilikan objek akad tanpa disertai imbalan.

Tidak boleh mengambil manfaat dari akad ini meskipun sudah disetujui oleh kedua belah pihak. (Sjahdeini \& Remy, 1999)

\section{Dasar Hukum Qardh}

Mungkin sejak adanya manusia di dunia ini, akad utang piutang telah dilakukan karena keadaan tertentu Dasar disyari'atkannya Qardh adalah Al-Qur'an, hadits dan ijma'.

1) Dalil Al-Qur'an

Dalam surat Al-Baqarah (2) ayat 245 Allah SWT berfirman

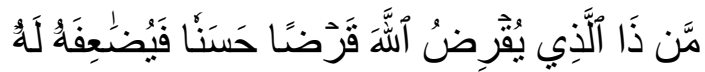

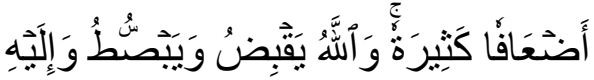

$$
\begin{aligned}
& \text { تُرْجَجَعُونَ }
\end{aligned}
$$

"Siapakah yang mau memberi pinjaman kepada Allah, pinjaman yang baik (menafkahkan harta di jalan Allah), maka Allah melipatgandakan kepadanya dengan lipat ganda yang banya." 
Adapun maksud dari ayat tersebut adalah Allah SWT menyeru kepada manusia untuk beramal shaleh, memberi infaq fi sabilillah dengan uang yang dipinjamkan, sehingga Allah SWT akan memberikan balasan yang berlipat ganda bagi hamba yang melaksanakan perintahnya. Dalam ayat lain Allah SWT berfirman dalam QS. At-Thagaabun (64) ayat 17 ,

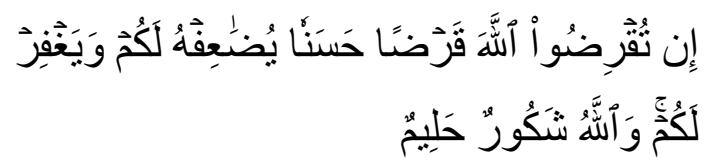

"Jika kamu meminjamkan kepada Allah pinjaman yang baik, niscaya Allah akan melipatgandakan pembalasannya kepadamu dan mengampuni kamu. Dan Allah maha pembalas jasa lagi maha penyantun."

Abdullah Yusuf Ali mengatakan bahwa: "Mengeluarkan harta dijalan Allah secara metafora disebut piutang yang baik." Dan menurut abdul-a'la maududi piutang yang baik adalah piutang yang dilaksanakan ikhlas untuk mencari ridha Allah SWT karena dia akan menambahkan dan membalaskannya dengan balasan yang berlipat ganda. (Chaundry, 2017)

2) Dalil Hadist

Ibnu Majah meriwayatkan hadist yang bersumber dari ibnu mas'ud r.a dari Nabi SAW, beliau bersabda: "Tidaklah seorang muslim memberi pinjaman kepada orang muslim yang lain dua kali melainkan pinjaman itu (berkedudukan) seperti sedekah satu kali." (HR. Ibnu Majah)

3) Dalil Ijma'

Bahwa semua kaum muslimin telah sepakat dibolehkan utang piutang karena Qardh memiliki kebaikan bagi kedua belah pihak untuk saling tolong menolong. Abu Hurairah berkata, "Rasulullah $S A W$ bersabda, barangsiapa melepaskan dari seorang muslim satu kesusahan dari kesusahan-kesusahan dunia, niscaya Allah melepaskan dia dari kesusahan-kesusahan hari kiamat. Barangsiapa memberi kelonggaran kepada seseorang yang sedang kesusahan, niscaya Allah akan memberi kelonggaran baginya di dunia dan diakhirat. Dan Allah selamanya menolong hamba-Nya, selama hamba-Nya mau menolong saudaranya.

\section{B. Qardh sebagai Akad Tabarru'}

Akad tabarru' adalah segala perjanjian yang menyangkut non-for profit (transaksi nirlaba). Transaksi ini pada hakikatnya bukan transaksi bisnis atau mencari keuntungan komersil. Akad tabarru' dilakukan dengan tujuan tolong menolong dalam rangka berbuat kebaikan. Dalam akad tabarru' pihak yang berbuat kebaikan tersebut tidak berhak mensyaratkan imbalan apa pun kepada pihak lainnya. Imbalan dari akad tabarru' 
ialah dari Allah SWT, bukan dari manusia. Namun demikian, pihak yang berbuat kebaikan tersebut boleh meminta kepada counterpart-nya untuk sekedar menutupi biaya yang dikeluarkannya untuk dapat melakukan akad tabarru' tersebut. Namun ia tidak boleh sedikitpun mengambil laba dari tabarru'.

Menurut Santoso, karakteristik pembiayaan Al-Qardh diantaranya adalah:

1) Tidaklah diperkenankan mengambil keuntungan apapun bagi muqridh dalam pembiayaan Al-Qardh, hal tersebut sama dengan riba.

2) pembiayaan Al-Qardh menggunakan akad pinjam-meminjam, ketikang barang atau uang telah diterima oleh mustaqridh maka barang atau uang telah berada dalam tanggung jawabnya dengan kewajiban untuk mengembalikan sama dengan pada saat meminjam.

3) Al-Qardh biasanya dalam batas waktu tertentu, namun jika tempo pembayarannya diberikan maka akan lebih baik, kerena lebih memudahkannya lagi.

4) Jika dalam bentuk barang asli yang dipinjamkan masih ada seperti semula maka harus dikembalikan dan jika telah berubah maka dikembalikan semisalnya atau seharganya.
5) Jika dalam bentuk uang maka nominal pengembalian sama dengan nominal peminjaman.

\section{Ketentuan akad Qardh berdasar pada Fatwa DSN-MUI}

Secara mendasar, karena sifat dan tujuan Qardh adalah tolong menolong, maka transaksi ini terlepas dari unsur komersial dan usaha yang berorientasi pada keuntungan (profit oriented).

Pelaksanaan program Al-Qardh didasarkan pada Peraturan Bank Indonesia (PBI) No. 7/46/PBI/2005 tentang akad penghimpunan dan penyaluran dana bagi bank yang melaksanakan kegiatan usaha berdasarkan prinsip syariah; dan Peraturan Bank Indonesia (PBI) No. 9/19/PBI/2007 tentang Pelaksanaan Prinsip syariah dalam Kegiatan Penghimpunan Dana dan Penyaluran Dana serta Pelayanan Jasa Bank Syariah. (Purwadi, Al-Qardh dan AlQardhul Hasan sebagai Wujud Pelaksanaan Tanggung Jawab Sosial Perbankan Syariah, 2014)

Seperti dijelaskan dalam Fatwa DSN MUI No. 19/DSN-MUI/IV/2001 tentang AL-Qardh. Ketentuan umum alQardh yaitu:

1) Al-Qardh adalah pinjaman yang diberikan kepada nasabah yang memerlukan. 
Febri Annisa Sukma, dkk. Konsep dan Implementasi Akad Qardhul Hasan Pada Perbankan Syariah dan Manfaatnya

2) nasabah Al-Qardh wajib mengembalikan jumlah pokok yang diterima pada waktu yang telah disepakati bersama.

3) Biaya administrasi dibebankan kepada nasabah.

4) LKS dapat meminta jaminan kepada nasabah bilamana dipandang perlu.

5) Nasabah Al-Qardh dapat memberikan tambahan (sumbangan) dengan sukarela kepada LKS selama tidak diperjanjikan dalam akad.

6) Jika nasabah tidak dapat mengembalikan sebagian atau seluruh kewajibannya pada saat yang telah di sepakati dan LKS memastikan ketidakmampuannya, LKS dapat:
a. Memperpanjang jangka waktu pengembalian, atau

b. Menghapus (write off) sebagian atau seluruh kewajibannya.

Dengan ketentuan lain, bahwasannya:

1) Jika salah satu pihak tidak menunaikan kewajibannya atau jika terjadi perselisihan di antara para pihak, maka penyelesaiannya dilakukan melalui Badan Arbitrase Syari'ah setelah tidak tercapai kesepakatan melalui musyawarah.

2) Fatwa ini berlaku sejak tanggal ditetapkan dengan ketentuan jika di kemudian hari ternyata terdapat kekeliruan, akan diubah dan disempurnakan sebagaimana mestinya. (Sjahdeini \& Remy, 1999)

Dari ketentuan-ketentuan yang telah diatur tersebut, jika nasabah dalam hal ini tidak dapat mengembalikan atau terjadinya wanprestasi. LKS dapat memberikan sanksi kepada nasabah jika: (Budiman, 2013)

1) Ketika nasabah tidak menunjukkan keinginan mengembalikan sebagian atau seluruh kewajibannya dan bukan karena ketidakmampuannya, LKS dapat menjatuhkan sanksi kepada nasabah;

2) Sanksi yang dijatuhkan kepada nasabah sebagaimana dimaksud butir 1 dapat berupa dan tidak terbatas pada penjualan barang jaminan. Jika barang jaminan tidak mencukupi, nasabah tetap harus memenuhi kewajibannya secara penuh.

\section{Implementasi dan praktik Qardh di Perbankan Syari'ah}

Pelaksanaan program al-qardh dan alqardhul hasan didasarkan pada fatwa DSN-MUI Nomor: 19/DSN-MUI/IV/2001 tentang al-Qardh, Peraturan Bank Indonesia (PBI) No. 7/46/PBI/2005 tentang Akad Penghimpunan dan Penyaluran Dana bagi Bank yang Melaksanakan Kegiatan Usaha Berdasarkan Prinsip Syariah; dan Peraturan 
Bank Indonesia (PBI) No. 9/19/PBI/2007 tentang Pelaksanaan Prinsip Syariah dalam Kegiatan Penghimpunan Dana dan Penyaluran Dana serta Pelayanan Jasa Bank Syariah.

Satu-satunya akad berbentuk pinjaman yang diterapkan dalam perbankan syariah adalah Qardh dan turunannya Qardhul Hasan. Karena bunga dilarang dalam Islam, maka pinjaman Qardh maupun Qardhul Hasan merupakan pinjaman tanpa bunga. Lebih khusus lagi, pinjaman Qardhul Hasan merupakan pinjaman kebajikan yang tidak bersifat komersial, tetapo bersifat sosial. (Ascarya, 2007)

Pinjaman kebaikan, Al-Qardh digunakan untuk membantu keuangan nasabah secara cepat dan berjangka pendek. Produk ini digunakan untuk membantu usaha kecil dan keperluan sosial. Dana ini diperoleh dari dana zakat, infaq dan sodaqoh. Ketentuan mengenai Qardhul Hasan telah diatur dalam Fatwa DSN No. 19/DSN-MUI/IX/2000. (Imaniyati P. D., 2011)

Persoalan yang mendasar dalam aplikasi perbankan syariah adalah apakah al-Qardh dan al-Qardhul Hasan dapat menjadi sebuah pertanggung jawaban sosial di perbankan syariah? Dalam undang-undang nomor 21 Tahun 2008 tentang Perbankan Syariah, Pasal 2, 3, dan 4, menjelaskan bahwa perbankan syariah dalam menjalankan fungsinya bertujuan untuk menunjang pelaksanaan pembangunan nasional dalm rangka meningkatkan keadilan, kebersamaan dan pemerataan kesejahteraan rakyat. Sebagai salah satu implementasi tujuan tersebut perbankan syariah dapat menjalankan fungsi sosialnya dalam bentuk baitul mal, yaitu menerima dana yang berasal dari zakat, infak, sedekah, atau dana sosial lainnya dan menyalurkannya kepada masyarakat. (Purwadi, Al-Qardh dan AlQardhul Hasan sebagai Wujud Pelaksanaan Tanggung Jawab Sosial Perbankan Syariah, 2014)

Implementasi produk sosial didasarkan pada fatwa MUI No. 19/DSNMUI/IV/2001 tentang Qardh yang dananya bersumber dari bagian modal dan keuntungan yang disisihkan dari Lembaga Keuangan Syariah (LKS), serta lembaga lain atau individu yang mempercayakan penyaluran infaqnya lewat LKS. Pada tahun 2011, MUI kembali mengeluarkan fatwa Qardh dengan No. 79/DSNMUI/III/2011 yang sumber dananya berasal dari nasabah. Jika dibandingkan dengan fatwa MUI tahun 2001, fatwa MUI 2011 ini dimungkinkan dapat menimbulkan kemudharatan yang lebih besar apabila terjadi piutang Qardh yang tidak tertagih karena sumber dananya dari nasabah. 
Dalam melaksanakan fungsinya bank syariah melaksanakan transaksi yang sifatnya tolong menolong yaitu pinjaman Qardh atau Qardhul Hasan, yaitu pinjaman uang Cuma-Cuma. Sesuai karakteristik ekonomi syariah uang bukan komoditi sehingga tidak diperkenalkan uang menghasilkan atau bertambah uang. Pinjaman dengan akad ini dilakukan oleh Bank Syariah dalam transaksi yang bersifat tolong menolong, penyaluran Zakat Nasional (BAZNAZ), bisa juga untuk talangan Haji, talangan cerukan atau overdraf dari rekening wadiah, transaksi rahn, hawalah dan sejenisnya. (Nurnasrina \& Adiyes, 2017)

Objek dari pinjaman Qardh biasanya adalah uang atau alat tukar lainnya, yang merupakan transaksi pinjaman murni tanpa bunga ketika peminjam mendapatkan uang tunai dari pemilik dana (Bank) dan hanya wajib mengembalikan pokok utang pada waktu tertentu di masa yang akan datang. Peminjam atas prakarsa sendiri dapat mengembalikan lebih besar sebagai ucapan terima kasih. (Ascarya, 2007)

Akad Qardh biasanya diaplikasikan di perbankan syariah seperti:

1) Penyaluran dan zakat yang bersifat produktif (dana bergulir) yang diperuntukan sesuai syariat yaitu diberikan kepada delapan hasnaf. Biasanya penyaluran zakat ini merupakan produk kerja sama antara BAZNAS dengan bank syariah, BAZNAS sebagai lembaga penghimpun dana dan penyalurannya melewati model transaksi bank.

2) Pembiayaan pengurusan haji, berdasarkan Fatwa DSN No: 29/DSN-MUI/VI/2002 tentang Pembiayaan Pengurusan Haji Lembaga Keuangan Syariah, menetapkan ketentuan sebagai berikut:

a. Dalam pengurusan haji bagi nasabah, LKS dapat memperoleh imbalan jasa (ujrah) dengan menggunakan prinsip al-ijarah sesuai Fatwa DSN-MUI No. 9/DSNMUI/IV/2000

b. Apabila diperlukan, LKS dapat membantu menalangi pembayaran BPIH nasabah dengan menggunakan prinsip al-Qardh sesuai Fatwa DSN-MUI No. 19/DSNMUI/IV/2001

c. Jasa pengurusan haji dilakukan LKS tidak boleh dipersyaratkan dengan pemberian talangan haji.

d. Besar imbalan jasa al-Ijarah tidak boleh didasarkan pada jumlah talangan al-Qardh yang diberikan LKS kepada nasabah.

3) Anjak piutang yang berlandaskan pada Fatwa DSN No. 67/DSN-MUI/III/2008 tentang Anjak piutang syariah.

4) Letter of Credit (L/C) Impor dan Letter of Credit Ekspor, yang berlandaskan pada Fatwa DSN-MUI No. 34/DSNMUI/IX/2002 tentang L/C Impor Syariah 
dan Fatwa DSN-MUI No. 35/DSNMUI/IX/2002 tentang L/C Ekspor Syariah.

5) Sebagai produk pelengkap kepada nasabah yang telah terbukti loyalitas dan bonefiditasnya yang menumbuhkan dana talangan segera untuk masa yang relatif pendek. Nasabah tersebut akan mengembalikan secepatnya sejumlah dana yang dipinjamnya tersebut.

6) Sebagai fasilitas yang memerlukan dana cepat sedangkan ia tidak bisa menarik dananya karena misalnya pengusaha tersimpan dalam bentuk deposito.

7) Sebagai pinjaman kepada pengusaha kecil, dimana menurut perhitungan bank akan memberatkan si pengusaha bila diberikan pembiayaan dengan skema jual beli, ijarah, atau bagi hasil.

8) Sebagai produk untuk menyumbang ke sektor kecil atau membantu sektor sosial.

Ulama-ulama tertentu membolehkan pemberi pinjaman untuk membebani biaya jasa pengadaan pinjaman. Biaya jasa ini bukan merupakan keuntungan, melainkan merupakan biaya aktual yang dikeluarkan oleh pemberi pinjaman, seperti biaya sewa gedung, gaji pegawai dan peralatan kantor. Hukum Islam memperbolehkan pemberi pinjaman untuk meminta kepada peminjam untuk membayar biaya-biaya operasi di luar pinjaman pokok, tetapi agar biaya ini tidak menjadi bunga terselubung komisi atau biaya ini tidak boleh dibuat proporsional terhadap jumlah pinjaman. (Ascarya, 2007)

\section{E. Anjuran Menyegerakan Pengembalian Pinjaman Qardh}

Akad Qardh termasuk ke dalam akad tabarru', karena di dalamnya ada unsur menolong dalam kebaikan dan ketakwaan. Oleh sebab itu, muqridh berhak meminta agar harta yang dipinjam dikembalikan dengan segera. Dalam persoalan pembayaran utang, Nabi telah menganjurkan agar seseorang menyegerakan pembayaran utangnya. Karena menunda pembayaran utang bagi orang mampu termasuk kezaliman. Dalam hadist Nabi SAW. Telah dijelaskan:

“menunda-nunda (pembayaran) yang dilakukan oleh orang yang mampu adalah suatu kezaliman, maka dapat dikenakan sanksi dan dicemarkan nama baiknya." (HR. Bukhari)

Bila seseorang tidak mampu membayar utangnya. Disunatkan terhadap orang yang berpiutang untuk menunda tagihan kepada orang tersebut karena memberikan kelonggaran kepada orang yang kesusahan akan diberikan kemudahan oleh Allah pada hari kiamat.

Bila orang yang sudah jatuh bangkrut memiliki kesempatan untuk membayar utang, tetapi dilalaikan, maka semua orang yang mengutangkan kepadanya dibolehkan 
mengambil hartanya dengan paksa dan diberi hukuman.

Fatwa DSN dan KHES bila peminjam kesulitan dalam membayar utangnya, maka solusi alternatif memperpanjang jangka waktu pelunasan utang menurut prinsip perbankan adalah menambah jangka waktu (hari/bulan/tahun), dalam praktiknya semakin lama jangka waktu semakin banyak margin yang ditarik oleh bank. Akan tetapi, semakin lama jangka waktu cicilan, akan semakin kecil jumlah per-cicilannya, namu akan semakin banyak total uang yang harus dilunasi. (Mujahidin, 2016)

\section{F. Manfaat Qardh dalam Praktik Perbankan Syariah}

Al-Qardh dan al-Qardhul Hasan merupakan misi sosial perbankan syariah. Misi sosial ini sebagai upaya tanggung jawab sosial perbankan syariah yang bertujuan meningkatkan citra bank, meningkatkan loyalitas masyarakat terhadap bank syariah, dan menumbuhkan pemberdayaan masyarakat. Hal ini, senada dengan dengan perspektif ajaran Agama Islam, bahwa aktivitas finansial dan perbankan dalam dunia modern seperti sekarang ini mengandung dua prinsip, yaitu prinsip al-ta'awun. (Purwadi, AlQardh dan Al-Qardhul Hasan sebagai
Wujud Pelaksanaan Tanggung Jawab Sosial Perbankan Syariah, 2014)

Manfaat akad Qardh dalam praktik perbankan syariah banyak sekali diantaranya sebagai berikut:

1) Memungkinkan nasabah yang sedang dalam kesulitan mendesak untuk mendapatkan talangan jangka pendek.

2) Al-Qardhul Hasan juga merupakan salah satu ciri pembeda antara bank syariah dan bank konvensional yang di dalamnya terkandung misi sosial, di samping misi komersial.

3) Adanya misi sosial kemasyarakatan ini akan meningkatkan loyalitas masyarakat terhadap bank syariah. (Mardani, 2012)

4) Pedagang kecil memperoleh bantuan dari bank syariah untuk mengembangkan usahanya, sehingga misi sosial bagi bank syariah dalam membantu masyarakat miskin.

5) Dapat mengalihkan pedagang kecil dari ikatan utang rentenir, dengan mendaptkan utang dari bank syariah tanpa bunga.

\section{SIMPULAN}

Berdasarkan uraian dan rumusan masalah yang dikemukakan di atas, dapat ditarik kesimpulan sebagai berikut:

Akad Qardh pada hakikatnya adalah bentuk pertolongan dan kasih sayang bagi yang meminjam, bukan suatu sarana untuk mencari keuntungan bagi yang 
memijamkan, di dalamnya tidak ada imbalan dan kelebihan pengembalian. Namun dalam Qardh ini mengandung nilai kemanusiaan dan sosial dimana dalam akad ini peminjam tidak boleh mensyaratkan keuntungan dalam pinjaman dan ia boleh menerima lebih jika peminjam memberikannya dalam jumlah yang lebih selama tidak dipersyaratkan di awal dan tidak diperjanjikan.

Sifat Qardh tidak memberikan keuntungan finansial. Karena itu, pendanaan Qardh dapat diambil menurut kategori. Pertama, akad Al-Qardh yang diperlukan untuk membantu usaha sangat kecil dan keperluan sosial, dapat bersumber dari dana zakat, infaq, dan sedekah. Kedua, akad Al-Qardh yang diperlukan untuk membantu keuangan nasabah secara cepat dan berjangka pendek. Talangan dana tersebut dapat diambilkan dari modal bank.

Implementasi produk sosial didasarkan pada fatwa MUI No. 19/DSNMUI/IV/2001 tentang Qardh yang dananya bersumber dari bagian modal dan keuntungan yang disisihkan dari Lembaga Keuangan Syariah (LKS), serta lembaga lain atau individu yang mempercayakan penyaluran infaqnya lewat LKS.

Dalam Praktiknya Qardh di Perbankan Syariah banyak di implementasikan pada produk-produk seperti Produk kerjasama dalam Penyaluran Zakat Produktif dengan BAZNAS, Dana Talangan Haji, Pembiayaan Usaha, Letter of Credit (L/C) Impor dan Ekspor Syariah dan lain-lain yang merujuk berdasarkan Fatwa DSNMUI yang telah dikeluarkan.

Bank boleh menerima Ujrah atau Imbalan dari akad Qardh selama tidak diperjanjikan oleh bank dan bersifat sukarela dari nasabah sebagai tanda terima kasih.

Qardh dalam Praktik Perbankan syariah memiliki banyak manfaat tidak hanya bagi nasabah karena dirasa sangat membantu dan tertolong juga bagi Bank itu sendiri, Qardh ini tidak akan merugikan Bank Syariah dan justru itulah kelebihan dari Bank syariah yang dalam operasionalnya berbeda dari Bank Konvensional, tidak hanya mengejar keuntungan tetapi di dalamnya terdapat unsur sosial tabarru' atau tolong menolong. 



\section{DAFTAR PUSTAKA}

Ascarya. (2007). Akad \& Produk Bank Syariah. Jakarta: PT. RajaGrafindo Persada.

Budiman, F. (2013). Karakteristik akad AlQardh sebagai akad Tabarru'. karakteristik akad pembiayaan, 412.

Chaundry, M. S. (2017). Prinsip Dasar System Ekonomi Islam (Prinsip Dasar). Jakarta: Prenada Media.

Dr. Neneng Nurhasanah, M., \& Panji Adam, S. M. (2017). Hukum Perbankan Syariah (Konsep dan Regulasi). Jakarta: Sinar Grafika.

Imaniyati, P. D. (2009). Perkembangan Regulasi Perbankan Syariah di Indonesia: Peleuang dan Tantangan. Syiar Hukum, 21.

Imaniyati, P. D. (2011). Pengaruh Perbankan Syariah terhadap Hukum Perbankan Nasional. Syiar Hukum, 214.

Mardani, D. (2012). FIqh Ekonomi Islam : Fiqih Muamalah. Jakarta: Kencana.

Masruri, A., Zainur, A., \& Khairul, M. (2018). Konsep dasar dan Implementasi Qardh (Pinjaman). Sains Ekonomi Islam, 3.

Mujahidin, A. (2016). Hukum Perbankan Syariah. Jakarta: PT. RajaGrafindo Persada.

Nurnasrina, \& Adiyes, P. (2017). Kegiatan Usaha Bank Syariah. Yogyakarta: Kalimedia.
Purwadi, M. I. (2014). Al-Qardh dan AlQardhul Hasan Sebagai Wujud Pelaksanaan Tanggung Jawab Perbankan Syariah. Ius Quia Iustum Law Journal, 19.

Purwadi, M. I. (2014). Al-Qardh dan AlQardhul Hasan sebagai Wujud Pelaksanaan Tanggung Jawab Sosial Perbankan Syariah. Jurnal Hukum IUS, 27.

Research, I., \& Institute, T. (2007). Qardh and Qardhul al-Hasan. Islamic Research and Training Institute.

Satrio, M. A. (2009). Qardhul Hasan sebagai wujud pelaksanaan CSR dan kegiatan filantropi lembaga keuangan syari'ah untuk pemberdayaan masyarakat. islamic economics, 109.

Sjahdeini, \& Remy, S. (1999). Perbankan Islam dan Kedudukannya dalam Tata Hukum Perbankan Indonesia. Jakarta: PT. Pustaka Utama Grafiti.

Usanti, T. P. (2017). Akad Al-Qardh dalam Transaksi Pinjam Meminjam. Islamic Economics, 19. 